\title{
ENSURING THE PROFITABILITY AND CONTINUITY OF PRIVATE HEALTH INSURANCE
}

\author{
DR. YOHANNA GYANG JUGU \\ DEPARTMENT OF ACTUARIAL SCIENCE \\ UNIVERSITY OF JOS \\ E-mail: juguy@unijos.edu.ng
}

\author{
DOI: $10.31364 / \mathrm{SCIRJ} / \mathrm{v} 7.17 .2019 . P 0719676$ \\ http://dx.doi.org/10.31364/SCIRJ/v7.i7.2019.P0719676
}

\begin{abstract}
Every Insurance undertaking has to do with risk evaluation to ensure that the insurance business is always solvent and continue to exist. Health insurance like life insurance funds and non-life insurance funds must ensure that it remains in business and can discharge their liabilities as at when due. Hence the need to keep adequate reserves or economic capital always. The paper derives the methodology for deriving premiums taking into consideration the incidence of sickness and the medical bills. They are both assumed to follow a normal distribution with known means and standard deviations. The extra liability or reserves that must be kept is shown in a functional relationship. Various probabilities of ruin are used to compute the reserves. The reserves increases from $12.089 \%$ of the expected liability for a probability of ruin of 0.25 to $53.562 \%$ of normal liability for a probability of ruin of .001. The Insurance provider wants an almost guarantee that ruin or insolvency is impossible it goes for a probability of ruin of 0.001 and reserves is more than half the expected liabilities .
\end{abstract}

Keywords: incidence of sickness, medical claims, normal distribution, variances, probability of ruin and economic reserves, solvency.

\section{INTRODUCTION}

The health sector in any country has been recognized as the primary empire of growth and development (obansa and akingbade, 2014). Therefore the economic reserve for insurance is of great importance.

Insurance providers over the years have had failures because their liabilities exceed their accumulate assets. There is need to forecast on the long term viability of the funds either with profit or without profit to meet its liabilities and also statutory required solvency ratio.

Solvency margin refers to a defined safety margin by which a company's assets must exceed its liabilities. Insurance companies or insurance providers are expected, like any company, to be able to evaluate their risk and ensure measures to adequately mitigate all risks continuously and consistently. A solvency margin acts as an extra guard in the event that risk occurrence exceeds the anticipated range for which measures have been taken; it serve to ensure that when supervisory authority involve their action to liquidate a company, there exist sufficient funds to meet their liabilities.

The paper sets out the expected liabilities and assets build up. There are various techniques for arriving at solvency margin or reserves. 
The paper will use the Economic Scenario approach to calculate the economic capital by analyzing the change in the present value of future profits under different assumptions.

\section{LITERATURE REVIEW}

The 1970's is deemed the origin of insurance rules in Europe, as this is when the European Union (EU) commission decided on an approach involving two steps i.e. Solvency I and

Solvency II (Doff, 2008, Linder et al, 2004, and Eling et al 2008).

In EU 1973 and 1979 solvency regulation, set out two directives requiring insurers to establish a capital buffer (common minimum standard) to cope with the uncertainty of insurance business, the aim was to detect threats early in insurance firms so as to allow supervisor authorities ensure measure to secure policy holders, Eling and Holz muller (2008) noted that four systems ground the world today can be identified as good examples of different approaches to securing insurance funds as other system can be likened to them; these are the United States (U.S), European Union (E.U), New Zealand and Switzerland. They argued that the U.S. insurance market which as at 2006 held approximately $31 \%$ of the world's premium income ( $\$ 1,170$ billion) has solvency regulation varied between its states. Prior to 1994 they relied on fixed minimum capital standards, however since then their National Aggregation of Insurance Commission (NAIC) developed RBC to ensure a more accurate reflection of size and risk exposure.

\section{METHODOLOGY}

We consider four risks in the health insurance liabilities; incidence of frequency of sickness, medical bills per sickness, expense risks and investment return risks.

\section{Liabilities}

Let $l_{x}$ be the number of people aged $\mathrm{x}$ in the population, which is assumed to be stationary.

The proportion at age $\mathrm{x}$ sick is $\mathrm{P}_{\mathrm{x}}$ and is normally distributed with mean $\mu_{\mathrm{IX}}$ and variance $\delta^{2}{ }_{\mathrm{IX}}$,

$\mathrm{N}\left(\mu_{\mathrm{IX}}, \delta^{2}{ }_{\mathrm{IX}}\right)$

The medical bills $\mathrm{M}_{\mathrm{x}}$ for a life aged $\mathrm{x}$ is normally distributed with mean $\mu_{2 \mathrm{X}}$ and variance $\delta^{2}{ }_{2 \mathrm{X}} \mathrm{N}\left(\mu_{2 \mathrm{X}}, \delta^{2}{ }_{2 \mathrm{X}}\right)$.

The overhead expenses incurred that enabled commencement such as buildings is taken as $G$ and yearly operating expenses $S_{t}$ (including staff salaries) is taken as a function of time to cater for salary escalation.

The expected cost of medical bills for a life aged $x$ is $P_{x} M_{x}$ and for all the lives age $x$, it will be $\sum_{x=0}^{\infty} \quad 1_{x} E\left(P_{x}\right) E\left(M_{x}\right)$

Let $\left(\mathrm{P}_{1} \mathrm{M}_{1}, \mathrm{P}_{2} \mathrm{M}_{2} \ldots \ldots \ldots \ldots \ldots \mathrm{P}_{\mathrm{n}} \mathrm{M}_{\mathrm{n}}\right)$ denote a random sample of size $\mathrm{n}$ from e bivariate normal distribution with probability density function $(\mathrm{P}, \mathrm{M})$ and parameters $\mu_{\mathrm{I}}, \mu_{2}, \delta_{\mathrm{I}}^{2}, \delta_{2}^{2}$, and $P$ where e is the correlation between $\mathrm{P}$ and $\mathrm{M}$. Let $\mathrm{P}$ be the mean $\mathrm{P}_{1}, \mathrm{P}_{2} \ldots \ldots \ldots \ldots$ $\mathrm{P}_{\mathrm{n}}$ and $\mathrm{M}$ be mean of $\mathrm{M}_{1}, \mathrm{M}_{2}, \ldots \ldots \ldots \ldots \ldots \mathrm{M}_{\mathrm{n}}$.

$\mathrm{P}=\sum_{x=1}^{n} \quad \mathrm{P}_{\mathrm{i}} / \mathrm{n} ; \mathrm{M}=\overline{\sum_{x=1}^{n}} \quad \mathrm{M}_{\mathrm{i}} / \mathrm{n}$

WWW.scirj.org

(C) 2019, Scientific Research Journal

http://dx.doi.org/10.31364/SCIRJ/v7.i7.2019.P0719676 
Using the principles of moment generating function of bivariate normal distribution of $\mathrm{P}$ and $\mathrm{M}$ has bivariate normal distribution with mean $\mu_{\mathrm{Ix}}, \mu_{2 \mathrm{x}}$ and correlation coefficient $P$.

The cost of medical bills for all ages $=\sum_{x=0}^{\infty} \quad 1_{x} E\left(P_{x}\right) E\left(M_{x}\right)=\sum_{x=0}^{\infty} \quad C_{n} \mu_{1 x} x \mu_{2 x}$.

Overhead expenses which is taken as a $\mathrm{H}$ is amortized over 10 years. Hence yearly cost is $0.1 \mathrm{H}$. Operating expenses is taken as $\mathrm{S}_{\mathrm{t}}$ which is function of $\mathrm{t}$, time. Taking $\mathrm{r} \%$ as the loading for profit and $\mathrm{k} \%$ for contingencies.

Our Premium for all age $\mathrm{x}$ for each year.

Prem $=(1+\mathrm{k}+\mathrm{r})\left\{\sum_{x=0}^{\infty} \quad 1_{\mathrm{x}} \mu_{1 \mathrm{x}} \mathrm{x} \mu_{2 \mathrm{x}}+0.1 \mathrm{H}\right\}$

$$
\sum_{x=0}^{\infty} \quad 1_{\mathrm{x}}
$$

At $95 \%$ confidence, the incidence of sickness and medical bills falls into these confidence levels, $\mathrm{Z}=1.96$

$\mu_{1 x} \pm Z \delta_{\text {Ix }}^{2}$ and $\mu_{2 x} \pm Z \delta_{2 x}^{2}$

If we introduce the single premium for the business as a continuity, at time t.

$$
\operatorname{Prem}_{\mathrm{t}}=\frac{\mathrm{Z}_{\mathrm{t}}(1+\mathrm{i})^{-\mathrm{t}}}{\sum_{x=0}^{\infty} 1_{\mathrm{x}}}=\frac{\mathrm{Z}_{\mathrm{t}}(1+\mathrm{i})^{-\mathrm{x}-\mathrm{t}}}{\sum 1_{\mathrm{x}}(1+\mathrm{i})^{-\mathrm{x}}}
$$

Where $Z_{t}=(1+k+r)\left(\sum_{x=0}^{\infty} \quad 1_{x} \mu_{1 x} \mu_{2 x}+S_{t}+0.1 H\right)$

At $95 \%$ confidence, on the upper limit, liability, $\mathrm{Z}_{\mathrm{t}}$

$\mathrm{Z}_{\mathrm{t}}=(1+\mathrm{k}+\mathrm{r})\left\{\sum_{x=0}^{\infty} \quad 1_{\mathrm{x}}\left(\mu_{1 \mathrm{x}}+\mathrm{Z} \delta_{\mathrm{Ix}}\right)\left(\mu_{2 \mathrm{x}}+\mathrm{Z} \delta_{2 \mathrm{x}}\right)+\mathrm{S}_{\mathrm{t}}+0.1 \mathrm{H}\right\}$

If operating expenses, $S_{t}$ is escalating at the rate s per year, $S_{t}=(1+s)^{t}$,

$S_{t}=S(1+s)^{t}$

$\mathrm{Z}_{\mathrm{t}}=(1+\mathrm{k}+\mathrm{r})\left\{\sum_{x=0}^{\infty} \quad 1_{\mathrm{x}}\left(\mu_{1 \mathrm{x}}+\mathrm{z} \delta_{\mathrm{Ix}}\right)\left(\mu_{2 \mathrm{x}}+\mathrm{z} \delta_{2 \mathrm{x}}\right)+\mathrm{S}(1+\mathrm{s})^{\mathrm{t}}+0.1 \mathrm{H}\right\}$

The additional liabilities unexpected at any confidence level at time $\mathrm{t}$

$\mathrm{t}=(1+\mathrm{k}+\mathrm{r})\left\{\sum_{x=0}^{\infty} \quad 1_{\mathrm{x}}\left(\mu_{1 \mathrm{x}} \mathrm{Z} \delta_{\mathrm{x}}^{2}+\mathrm{Z} \delta_{1 \mathrm{x}} \mu_{2 \mathrm{x}}+\mathrm{Z}^{2} \delta_{1 \mathrm{x}} \delta_{2 \mathrm{x}}\right)+\mathrm{S}\left\{(1+\mathrm{S})^{\mathrm{t}}-1\right\}\right.$

These unexpected liabilities require reserves set aside to make the health insurance business solvent.

In the language of ruin probability the probability is 0.025 or $2.5 \%$ of the times will the reserves for extra liability fail.

www.scirj.org

(C) 2019, Scientific Research Journal

http://dx.doi.org/10.31364/SCIRJ/v7.i7.2019.P0719676 
Let $\mathrm{F}(\mathrm{x})=1 / \sqrt{2} \pi \int_{-\infty}^{x} e^{-1 / 2 t^{2}} d t$

\begin{tabular}{|l|l|}
\hline $\mathrm{F}(\mathrm{x})$ & $\mathrm{Z}$ (score) \\
\hline .999 & 3.090 \\
\hline .995 & 2.576 \\
\hline .990 & 2.326 \\
\hline .975 & 1.960 \\
\hline .950 & 1.645 \\
\hline .75 & .674 \\
\hline
\end{tabular}

Reserves $R_{t}$ is a function of $R_{t}=f\left(k, r, l_{x}, z, \delta_{1 x}, \delta_{2 x}, S, s, t\right)$.

\section{CASE STUDY}

Table 1: Medical Bills

Age Group: Abridged Life Table

\begin{tabular}{|c|c|c|c|c|c|}
\hline & $0-9$ & $10-29$ & $30-49$ & $50-69$ & $>70$ \\
\hline $\mathrm{L}_{\mathrm{x}}$ & 90069 & 86969 & 80935 & 63670 & 18700 \\
\hline $\begin{array}{c}\text { Proportion sick } \\
\text { per week }\end{array}$ & .002 & .0015 & 0.003 & .003 & .002 \\
$\mu_{1 \mathrm{x}}$ & & & & & \\
\hline $\begin{array}{c}\text { Standard } \\
\text { deviation of } \\
\text { proportion sick } \delta_{1 \mathrm{x}}\end{array}$ & .0003 & .0003 & .00025 & 0.000032 & .00041 \\
\hline $\begin{array}{c}\text { Medical bill per } \\
\text { week }\end{array}$ & 5,000 & 7,200 & 5,500 & 5100 & 2000 \\
$\mu_{2 \mathrm{x}}$ & & & & & \\
\hline
\end{tabular}

Www.scirj.org

(C) 2019, Scientific Research Journal

http://dx.doi.org/10.31364/SCIRJ/v7.i7.2019.P0719676 


\begin{tabular}{|c|c|c|c|c|c|}
\hline $\begin{array}{c}\text { Standard } \\
\text { deviation of } \\
\text { medical bill } \delta_{2 \mathrm{x}}\end{array}$ & 27.386 & 24.899 & 22.694 & 22.361 & 17.889 \\
\hline
\end{tabular}

$\mathrm{S}$ : operating expenses is taken as $\$ 2$ million per week and salary escalation is taken as $\mathrm{s} / 52$ per week and $\mathrm{s}$ is taken as $6 \%$.

Loading, $\mathrm{k}$ is $10 \%$ and loading for profit $\mathrm{r}$ is taken $15 \%$

Extra liability is $\mathrm{EZ}_{\mathrm{t}}$ at time $\mathrm{t}$

$\mathrm{EZ}_{\mathrm{t}}=(1+\mathrm{k}+\mathrm{r})\left\{\sum_{x=0}^{\infty} \quad 1_{\mathrm{x}}\left(\mathrm{z} \mu_{1 \mathrm{x}} \delta_{2 \mathrm{x}}+\mathrm{z} \mu_{2 \mathrm{x}} \delta_{1 \mathrm{x}}+\mathrm{z}^{2} \delta_{1 \mathrm{x}} \delta_{2 \mathrm{x}}\right)+\mathrm{S}\left\{(1+\mathrm{S})^{\mathrm{t}}-1\right\}\right.$

Normal liability that equates present value of assets at

$\mathrm{NL}=(1+\mathrm{k}+\mathrm{r})\left\{\sum_{x=0}^{\infty} \quad 1_{\mathrm{x}} \mu_{1 \mathrm{x}} \mu_{2 \mathrm{x}}+\mathrm{S}_{\mathrm{t}}+0.1 \mathrm{H}\right\}$

From the level study

Normal liability $=4272243$

Table 2: Economic Reserves.

\begin{tabular}{|l|l|l|l|l|}
\hline $\mathrm{F}(\mathrm{x})$ & Probability of Ruin & $\mathrm{Z}$ score & Economic Reserves & $\begin{array}{l}\text { Percentage } \\
\text { Liability }\end{array}$ \\
\hline .999 & .001 & 3.090 & $2,288,300$ & 53.562 \\
\hline .995 & .005 & 2.576 & $1,878,748$ & 43.976 \\
\hline .990 & 0.01 & 2.326 & $1,688,800$ & 39.530 \\
\hline .0975 & 0.025 & 1.96 & $1,401,353$ & 32.801 \\
\hline 0.950 & 0.05 & 1.645 & $1,184,596$ & 26.558 \\
\hline .75 & 0.25 & 0.674 & 516,443 & 12.089 \\
\hline
\end{tabular}

The economic reserve to be kept is $12.089 \%$ of the normal liability at time 0 for a probability of ruin of .25 . The economic reserve for a probability of ruin of .05 is $26.558 \%$ of normal liability. It rises to $53.562 \%$ for economic reserves of the normal liability for a probability of ruin of .001 . Thus, there is a chance of 1 , in 100 that when the economic reserve is $53.562 \%$ of normal liability, the health insurance programme can become insolvent. This can arise because of increment in the incidence of sickness and medical expenses.

www.scirj.org

(C) 2019, Scientific Research Journal

http://dx.doi.org/10.31364/SCIRJ/v7.i7.2019.P0719676 


\section{CONCLUSION}

There is need for a health insurance provider to have good estimates of the variables entering into the computations of premium, expectations of liabilities and assets. The probability distribution functions for each variable such as incidence of sickness and medical bills should be ascertained and adequate records of all claims and sickness incidence should be kept. This will enable the health provider to make realistic estimates according to her own experience.

\section{REFERENCES}

1. Berket, A. and Macdonald, A.S, 1999, "The effect of the native of the liabilities on the solvency and maturity payouts of a use life office fund; a stochastic evaluation” Insurance. Mathematics and Economics, Vol. 24 pp 117-138.

2. Eling M, Schmeiser, H; Schmit, T.T. and Madison, W; “The solvency II process overview and critical analysis” Risk Management and Insurance Review Vol. 10, No1, pp. 69-85.

3. European commission (2007) Proposal for new solvency requirement for insurance undertaking

4. Federal office of Private Insurance (FOPI) (2004) Whitepaper of the Swiss Solvency Test, FOPI, Bern November

5. Obansa, S.AJ and Akinnagbe O. (2013). Health care financing in Nigeria: Prospects and challenges. Mechteranian Journal of Social Sciences Vol 4 (1)

6. Ross, M.D, 1989, “Modelling a with profile life office” Journal of the Institute of Actuarial Vol. 116, pp 6971-716

www.scirj.org

(C) 2019, Scientific Research Journal

http://dx.doi.org/10.31364/SCIRJ/v7.i7.2019.P0719676 